\title{
Osmanlılar Niçin Kalyon İnşasından Bir Süre İçin Vazgeçtiler? (1656-1682)
}

\section{Why Did the Ottomans Temporarily Abandon the Construction of Galleons? (1656-1682)}

\author{
İdris Bostan* (1)
}

*Prof. Dr., İstanbul Üniversitesi, Edebiyat Fakültesi, Tarih Bölümü, İstanbul, Türkiye

\section{ORCID: İ.B. 0000-0003-0850-3705}

Sorumlu yazar/Corresponding author: İdris Bostan,

İstanbul Üniversitesi, Edebiyat Fakültesi, Tarih Bölümü, İstanbul, Türkiye

E-posta/E-mail: idrisbostan@gmail.com

Başvuru/Submitted: 15.06 .2020 Revizyon Talebi/Revision Requested: 30.06.2020

Son Revizyon/Last Revision Received: 12.07.2020

Kabul/Accepted: 13.07 .2020

\section{Atıf/Citation:}

Bostan, Idris. "Osmanlılar Niçin Kalyon İnşasından Bir Süre Içcin Vazgeçtiler? (1656-1682)." Tarih Dergisi - Turkish Journal of History, 71 (2020): 223-238

https://doi.org/10.26650/TurkJHist.2020.013

\section{öz}

Girid seferi sırasında (1645-1669), adanın fethi için sadece kara askerine ve savaş malzemelerine ihtiyaç duyulmamış, aynı zamanda adanın abluka altına alınması ve dışarıdan gelecek Venedik yardımlarının engellenmesi için güçlü bir donanmaya da ihtiyaç duyulmuştu. Kandiye kalesinin direnmesi sebebiyle kuşatma uzun süre devam etmiş ve denizlerde Osmanlı donanması ile Venedik donanması arasında bilhassa Çanakkale Boğazı çıkışında ve Girid adası civarında yaşanan pek çok deniz savaşı vuku bulmuştur. Venedik donanmasının kalyonlarla boğazı kapatması karşısında bunlara karşı kadırgalarla karşı koyamayacağını gören Osmanlı yönetimi 1650'de gemi teknolojisinde değişiklik yaparak kadırgadan kalyon düzenine geçti. Oldukça sancılı geçen bu dönemde teknik ve stratejik zafiyetlere kalyonlar için yetişmiş uzman denizcilerin yetersizliği eklenince kısmen başarılar elde edilmiş olsa da esas itibariyle ümit edilen sonuca ulaşmak mümkün olmadı. 1656'da yeniden eski düzene yani kadırga sistemine geri dönme kararı alındı. Bu makalede, gemi teknolojisinde yaşanan bu değişimlerin mahiyeti ve kalyon düzeninden bir süre için vazgeçilmesinin sebepleri dönemin arşiv belgeleri ve Osmanlı kaynakları esas alınmak ve Venedik kaynakları ile mukayese edilmek suretiyle incelenecektir.

Anahtar sözcükler: Girid, Osmanlı, Venedik, kadırga, kalyon, kaptanıderya

\section{ABSTRACT}

In the Cretan war of 1645-1669, the Ottomans needed siege troops and military ordnance to invade the island, as well as a formidable fleet for the purpose of blockading the island and preventing Venetian aid from reaching the defenders. The siege lasted longer than planned due to the successful resistance offered by the garrison of Candia; therefore several naval battles took place between the Ottoman and the Venetian navies, especially at the outlet of the Strait of the Dardanelles and around the island of Crete. At the time, the Ottoman government acknowledged its shortcomings in penetrating the Venetian navy that blockaded the strait with their galleons, thus, in the 1650's, the Ottoman shipwrights began to produce galleons in addition to galleys. In this challenging process, despite limited successes, the desired outcome could not be achieved because of the technical and 
strategic weaknesses along with the lack of expert sailors qualified for crewing galleons. Consequently, the Ottoman government decided to abandon the use of galleons and returned to galleys in 1656 . This article deals with the scope of the changes experienced in ship technology and examines the reasons for abandoning the use of galleons in the following decades based on Ottoman archival material and chronicles in comparison with Venetian sources.

Keywords: Crete, Ottoman navy, Venetian navy, galley, galleon, Grand Admiral

\section{Giriş}

Uzun yıllar süren Girid seferlerinin (1645-1669) Osmanlı gemi teknolojisinde sebep olduğu değişiklik neticesinde kürekli/kadırga düzeninden yelkenli/kalyon düzenine geçilmiş olsa da Akdeniz'deki deniz güçleri dengesinde Osmanlı kalyonlarının tam bir fayda sağlayamadığı görülmektedir. Buna karşılık, Çanakkale Boğazı çıkışını Osmanlı donanmasının geçişine kapatan Venedik donanması, çoğunlukla üstün konumlarını koruyarak kalyonları daha bir maharetle kullanmayı başarmışlardı.

Osmanlı kalyonları, mürettebatlarının yetersizliği yanında, denize çıktıkları ilk zamanlarda donanmadaki diğer gemilerle uyumlu ve müşterek hareket edememesi, kalyon taktik ve stratejilerine tam vakıf olmayan kalyon kapudanlarının savaşmak konusundaki çekingenlikleri gibi sebepler yüzünden genellikle başarısız olmuştu. Bu yüzden Osmanlı donanmasında yaklaşık yirmi yıllık bir dönem için kalyon terk edilmişti.

$\mathrm{Bu}$ sebeple bir savaş unsuru olarak kalyonların ilk kullanımı sırasında karşılaşılan zorlukları veya bazen de elde edilen başarıları örnekleri üzerinden incelemek ve belli bir dönem için de olsa kalyondan vazgeçilmesinin sebeplerini ortaya koymak gerekmektedir.

\section{Kaptanıderya Kara Murad Paşa Dönemi (1654-55)}

Osmanlı donanmasında kullanılan kalyonların ilk en önemli başarısı 1064 (1654) senesinde gerçekleşti. Kaptanıderya Kara Murad Paşa ${ }^{1}$ komutasında 21 Cemâziyelâhır'da (9 Mayıs 1654) altı mavna, kırk dört kadırga ve yirmi iki kalyon ile İstanbul'dan Girid seferi için hareket eden donanma, dört gün sonra (13 Mayıs) Çanakkale Boğazı'ndan çıkarken dışarıda bekleyen Giuseppe Delfino’nun komuta ettiği Venedik donanması ile karşılaştı. Osmanlı kaynaklarına göre Venedik donanmasında dört mavna, altı kadırga ve on sekiz kalyon bulunuyordu².

1 Kara Murad Paşa'nın kısa biyografisi için bk. İdris Bostan, İstanbul'un 100 Denizcisi, İstanbul 2014, s. 129131.

2 Kâtib Çelebi, Fezleke [Osmanl Tarihi (1000-1065/1591-1655)], haz. Z. Aycibin, İstanbul 2016, II, 1072-1073. Kara Çelebi-zâde, donanmanın İstanbul'dan hareket tarihi olarak 22 Cemâziyelâhır'1 (10 Mayıs) zikretmektedir (Kara Çelebi-zâde Abdülaziz Efendi, Ravzatü'l-Ebrâr Zeyli (Tahlil ve Metin) 1732, haz. Nevzat Kaya, TTK, Ankara 2003, s. 174-175). 
Venedik kaynaklarına göre ise, Venedik donanmasında sekiz kadırga, iki mavna ve on altı kalyon bulunuyordu. Bu gemilerin çoğu, Hollanda ve İngiltere'den kiralanmıştı ${ }^{3}$. Venedik donanması 1654 Nisan'ının son haftasında Alvise Mocenigo komutasında Çanakkale Boğazı önlerine gelmiştit ${ }^{4}$.

Osmanlı donanmasındaki kalyonlar önde, mavnalar arkada ve kadırgalar en geride dizilmek suretiyle rüzgârlı bir havada Venedik donanması üzerine harekete geçti ${ }^{5}$. Tam iki donanma birbirine çatmak üzere iken kaptanıderya Murad Paşa, bahriye kanunlarına aykırı olarak bir firkateye girdi ve donanma gemilerini arkadan sürerek savaşı başlattı. Böylece önemli bir kalyon savaşı başlamış oluyordu. Dönemin Osmanlı kaynakları başta Kâtib Çelebi ve Kara Çelebi-zâde olmak üzere bu savaşı oldukça tafsilatlı bir şekilde anlatmaktadir.

İki taraftan karşılıklı toplar atılması üzerine ortalık dumanla kaplanınca önce kalyonlar kapudanı Emir kapudan düşmanın patrona kalyonuna saldırarak üç saat kadar savaştı. İçindeki savaşçıların bir kısmı öldüğü ve bir kısmı yaralandığı için asker ümitsizliğe düşünce Venedik kalyonunu ateşe verdiler. Sağ kalanlar da denize atladığı için onları firkateler topladı.

İskenderiyeli Mehmed kapudan da bir başka Venedik kalyonuna sarılarak şiddetli bir savaşa tutuştuysa da düşman tarafı o kalyonu ateşe verince ikisi de yandı. Diğer taraftan Osmanlı patrona kalyonunun bir Venedik kalyonuna sarılması üzerine Korfu kapudanı beraberindeki iki gemi ile hücum etti. Osmanlı gemileri bunların tamamını Rumeli sahiline sıkıştırınca Venedik gemileri demir bıraktı. Osmanlı patronası karaya yaklaşmaktan çekindiği için bunlardan ayrılıp başka düşman gemilerini ele geçirmek için harekete geçti. Osmanlı mavnaları Venedik mavnalarını arkasından toplayıp birinin tirinketesini düşürünce hemen üzerine hücum etti, arkasından yedek gemisi gelince de mavnayı ele geçirdi. Bunun üzerine Venedik gemileri bölgeden uzaklaşmaya teşebbüs etti ise de kapudan Murad Paşa kendi baştardasına gelerek kenarda demirlemiş olan kalyonun üzerine yürüdü. $O$ sırada Bozcaada' da bulunan derya beyleri de geldiği için Korfu kapudanının yedek gemisini topa tutarak paramparça ettiler. Bunun üzerine düşman o gemiyi de ateşe verdi, kalyon ise rüzgârın yardımıyla oradan uzaklaşmasına rağmen arkasından atılan 200 top sebebiyle yelken ve halatları perişan halde kaçtı. Bu savaşta Venedik donanması sekiz gemisini kaybetti ve kalan on sekiz gemisi ile İmroz taraflarına çekildi. Adriyatik filosu komutanı Francesco Morosini

3 Anderson, Venedik kaynaklarına dayanarak Osmanlı donanmasında kırk kadırga, altı mavna ve otuz gemi bulunduğunu Delfino'nun resmi kayıtlarından hareketle de Osmanlıların ikinci bir donanmasında, Garp Ocaklarına ait on dört kalyon ve 22 bey kadırgası olduğunu, savaşın 16 Mayıs’ta meydana geldiğini belirtmektedir (R. C. Anderson, Naval Wars in the Levant 1559-1853, Liverpool 1952, s. 148).

4 Mocenigo o sırada 72 yaşında idi (Bruno Mugnai, The Cretan War, 1645-1671, The Venetian-Ottoman Struggle in the Mediterranean, Warwick 2018, s. 148).

5 Osmanlı donanmasındaki bu sıralanma şekli Venedik kaynaklarınca da teyid edilmektedir (Anderson, Naval Wars, s. 148). 
ölmüş, oğlu ve katipleri de esir olmuştu6 . Venedik kaynaklarına göre, donanma iki kalyonunu kaybetmiş, bir kadırgası yanmış, biri de Osmanlılar tarafından esir alınmıştı. Osmanlıların ise iki kalyonu yanmış, bir mavna ve bir kadırga kaybolmuştu. Sonuç olarak bu savaş, tam anlamıla bir Osmanlı zaferi idi ${ }^{7}$.

Donanma, Eski İstanbulluk önüne çekilerek Tunus ve Mısır kalyonlarını bekledi ve birlikte Bozcaada'nın Poyraz limanına demirlediler. Orada kaldıkları üç gün zarfında şehitleri defnettikten sonra Sakız’a giderek Cezayir'den gelen on bir kalyonla buluştu.

Osmanlı donanması daha sonra İskiri adasına ve oradan Eğriboz'a yöneldiğinde Osmanlı kaynaklarına göre on sekiz kadırga, altı mavna ve yirmi iki kalyondan oluşan yenilenmiş bir Venedik donanmasının ${ }^{8}$ Değirmenlik (Milos) adasında olduğu haberi alındı. Bunun üzerine elli kalyon, altı mavna ve seksen kadırgadan oluşan Osmanlı donanması İstendil'e (Tinos) döndü. Daha önce bey gemileri yolda rast geldikleri Livorno'lu bir korsan gemisini ada kenarında yakmışlardı. Değirmenlik adasında geceyi denizde geçiren Osmanlı donanması, 26 Receb (12 Haziran) sabahı adanın alt tarafında bulunan düşman donanmasını görünce büyük bir top savaşı başladı. Ancak, rüzgâr şiddetli olduğu için gemiler birbirine çatamayarak akşama doğru iki donanma birbirinden uzaklaştı. Osmanlı donanması, 22 Haziran sabahı bölgeden ayrıldı. Venedik donanması da 5 Temmuz'da müttefik donanmayla birleşmek üzere Çerigo (Çuka) adasına gitti. Böylece müttefik donanmasının gemi sayısı otuz dört kadırga, altı mavna ve otuz kalyona ulaştı ${ }^{9}$. 26 Şa ‘ban'da (12 Temmuz) yeniden İstendil adasının doğusuna asker çıkartarak adayı yağmaladı ve sonra Sakız’a, oradan gemileri yağlamak üzere Kara Foça'ya döndü. Bu sırada Osmanlı donanması, Sakız-Eğriboz hattında Venedik donanmasına karşı tedbir olmak üzere bir müddet denizlerde dolaşmış, Ağustos başlarına kadar hava muhalefeti yüzünden daha aşağıya gidememişti ${ }^{10}$.

Midilli, İmroz, Selanik ve İskiri’ye uğradıktan sonra 14 Şevval'de (28 Ağustos) tekrar Sakız’a gelen ve Tunus gemilerine geri dönmeleri için izin veren kaptanıderya, üç gün sonra donanma ile Girid'e gitmek üzere yola çıktı. Nakşa-Para yolunda bir düşman kalyonu, iki firkate görüldüğü için Rodos beyi Memi Paşa-zâde ile Anabolulu Abdi Paşa komutasında

6 Anderson iki donanma arasında yaşanan savaşta karşılıklı donanma gemilerinin karşı tarafın hangi gemileriyle çatıştıkları konusunda da bilgi vermektedir (Naval Wars, s. 148-149). Bu çatışmada kaptanıderya Murad Paşa'nın iç hizmetlilerinden dört kişi denize düşmüş ve çok sayıda asker de şehid olmuştu (Kâtib Çelebi, Fezleke, II, 1073). Kara Çelebi-zâde, Ravzatü'l-ebrâr Zeyli, s. 175.

7 Venedik kaynaklarına göre savaşın genel bir özeti için bk. Mugnai, The Cretan War, s. 148-151.

8 Kara Çelebi-zâde, kalyon sayısını kırk iki olarak kaydetmektedir (Ravzatü'l-ebrâr Zeyli, s. 176). Bu konuda ayrıca bk. İdris Bostan, “17. Yüzyılın İkinci Yarısında Osmanlı Gemi Teknolojisinin Değişimi: Kadırgadan Kalyona”, Beylikten Imparatorluğa Osmanlı Denizciliği, İstanbul 2015, dipnot 55. Anderson, bu savaşta Venedik donanmasında otuz üç kalyon, altı mavna, yirmi iki kadırga bulunduğunu yazmaktadır (Naval Wars, s. 151).

9 Anderson, Naval Wars, s. 152.

10 Anderson, Naval Wars, s. 152. 
dokuz bey gemisi gönderildi. Kalyon kolaylıkla ele geçirildiği gibi bir de şarap gemisi tutularak Bodrum'a gönderildi. Donanma ertesi gün Kandiye yakınındaki Kastro’ya gelerek Çayönü’nde demirledi. Girid serdarı Hüseyin Paşa Kapudan Paşa ile görüştükten sonra tekrar donanmaya geçen kaptanıderya Murad Paşa Kerpe adasına doğru hareket etti ${ }^{11}$. 13 Eylül'de Rodos'a giden Kapudan Paşa, bir Felemenk gemisi yedeğinde olduğu halde İstanbul'a doğru hareket etmek üzere iken Meis’te Mısır beyinin iki korsan kalyonunun saldırısına uğradığı haberini alınca onu kurtarmak üzere yedi bey gemisini görevlendirdi, bunlar da kalyonu yedeğine alıp getirdi. Nihayet Murad Paşa, 21 Zilka'de'de (3 Ekim) Rodos'tan ayrılarak Sisam ve Sakız üzerinden 20 Ekim'de İzmir'e geldi ve Kurban Bayramını (10 Zilhicce/22 Ekim) burada eda ettikten sonra derya beylerine izin verdi. Kendisi de İstanbul'a gitmek üzere denize açılan Murad Paşa, 28 Ekim'de Çanakkale Boğazı'na ulaştı ve nihayet 20 Zilhicce'de (1 Kasım 1654) Tersane'ye girdi. Beraberinde 800 zincirli esir getirdiği için Divan'da takdir edilen Kara Murad Paşa padişahın iltifatına mazhar oldu ${ }^{12}$.

\section{Kaptanıderya Zurnazen Mustafa Paşa Dönemi (1655-1656)}

Murad Paşa'nın 5 Receb 1065 'te (11 Mayıs 1655) sadrazam olması üzerine yerine Zurnazen Mustafa Paşa kaptanıderya tayin edildi (15 Receb 1065/21 Mayıs 1655) ${ }^{13}$. Kalyonların kesin olarak öne çıkması sayesinde kalyon sayısında da artış olmuştu. Bu sebeple de her sene Girid için donanmanın Akdeniz’e açılması mutat hale gelmişti. Nitekim, 7 Şa ‘ban 1065 'te (12 Haziran 1655) otuz iki kalyon, elli bir kadırga, sekiz mavna ve birkaç firkateden oluşan Osmanlı donanması Zurnazen Mustafa Paşa (1655-1656) komutasında İstanbul'dan yola çıktı. Donanma on gün sonra 16 Şa‘ban’da (21 Haziran) Çanakkale Boğazı çıkışına ulaştı. Venedik donanması önceki seneden daha güçlü ve hazırlıklı olarak altı kadırga, dört mavna ve yirmi altı kalyondan oluşuyordu. Venedik donanmasına Lazzaro Mocenigo kumanda ediyordu ${ }^{14}$.

Osmanlı donanması Venedik kalyonları ile öğle vakti karşılaştığında rüzgâr müsait olduğu için beklemeksizin derhal çatışmaya girdi. Her zamanki gibi önde kalyonlar, arkada sekiz mavna ve bir miktar kadırga, kalyonlarla aynı hizada ilerliyordu. Bu halde iken düşmanın top ateş hattına girdiklerinde akıntı, kalyonları Rumeli sahillerine sürükledi. Venedik kalyonları

11 Kâtib Çelebi, Fezleke, II, 1074-1075. Kara Çelebi-zâde, Ravzatü'l-ebrâr Zeyli, s. 177-181.

12 Kâtib Çelebi, Fezleke, II, 1075-1076; Kara Çelebi-zâde Abdülaziz Efendi, donanmanın İstanbul'a dönüş tarihini 21 Zilhicce (2 Kasım) olarak vermektedir (Ravzatü'l-ebrâr Zeyli, s. 182). Venedik kaynakları da Murad Paşa'nın ve donanmanın faaliyetlerini ve cereyan eden olayları bazı farklarla ama aşağı yukarı aynı şekilde ifade etmektedir (Anderson, Naval Wars, s. 152-153). Venedik donanma komutanı Alvise/Luigi Mocenigo'nun hastalanarak 27 Ekim'de Kandiye'de öldüğ̈̈ ve donanmayı Kandiye muhafızı Francesco Morosini'ye bıraktığ1 konusunda bk. Anderson, Naval Wars, s. 153.

13 Zurnazen Mustafa Paşa'nın kısa biyografisi için bk. Bostan, İstanbul'un 100 Denizcisi, s. 132-133.

14 Osmanlı kaynakları ile örtüşen bilgiler veren Anderson, 36 kalyon, 8 mavna ve 60 kadırgadan oluşan Osmanlı donanmasının 19 Haziran'da Çanakkale Boğazı'na geldiğini ve 21 Haziran'da savaşın cereyan ettiğini yazmaktadır (Naval Wars, s. 153). Ayrıca bk. Mugnai, The Cretan War, s. 151. 
yelken açarak üzerlerine gelirken Kaptanıderya baştardası, mavnalar ve diğer gemiler arkadan topa tutarak akşama kadar süren ${ }^{15}$ büyük bir savaş meydana getirdiler. Gemilerin seren ve direkleri kırıldı. Katırcızâde kalyonuna yedi Venedik gemisi saldırdığı için şiddetli savaş oldu. Kalyonun seren ve dümenleri kırılıp, halatları kopmuştu. İçinde 480 gazinin bulunduğu kalyondan sadece 30 kişi sağ kalmışt ${ }^{16}$ ve gemiyi yedeğine alan Venedik çekdirisi, kalyonun halatlarını keserek bırakmış ve diğer gemiler de yanaşamadığı için kendi haline kalmıştı. Rüzgâr, kuru tekne haline gelen kalyonu Anadolu tarafına sürüklemiş, sağ kalanlar karaya çıktıktan sonra gemiyi yakmışlardı. Osmanlı donanmasından sekiz geminin zayi olduğu çatışmada, iki gemisini kaybeden Venedik donanması yine de bölgeden uzaklaştırılmıştı. Osmanlı donanması güvenli bir yere çekilirken bey gemileri Bozcaada'ya gönderilmiş ve savaşta şehid olan 120 kişi adada defnedilmişti.

Savaş sırasında bir kısım kalyonlar büyük yararlık gösterdiği halde bir kısmı da bir miktar top atışı yaptıktan sonra Midilli’ye çekilmişti. Kaptanıderyanın beraberindeki kadırga ve kalyonlarla Midilli'ye gelmesi üzerine savaşta yararlık gösteren kalyon kapudanları İstanbul'dan davet edilerek taltif edildi. Kaptanıderya Mustafa Paşa, firar eden kalyon kapudanlarını şiddetle azarladı.

Donanma Sakız'a vardığında kaptanıderya kalyon ve mavnalara ihtiyaç olmadığı kanaatine vararak kalyonları İstanbul'a, mavnaları da Foça limanına gönderdi. Kaptanıderya Mustafa Paşa'nın kalyonlar hakkında bu kadar açık bir tavır sergilemesinin sebebi, muhtemelen daha önceki senelerde boğaz çıkışında yaşanan yenilgiler ve kalyon yapımı için alınan karardan maksadın elde edilememesi olmalıdır.

Bu sırada Venedik donanmasının Benefşe kalesini kuşattığı haberi gelince kaptanıderya karadan ve denizden bir harekât düzenleyerek Venedik donanmasını bölgeden uzaklaştırdı ve yeni bir başarı kazanmış oldu ${ }^{17}$. Halbuki 1655 'te, altı kadırga, dört mavna ve yirmi altı kalyondan oluşan Venedik donanması bir önceki seneden daha güçlü olarak bölgeye gelmişti. Yine bu sene Tunus'un bir İngiliz saldırısına uğraması yüzünden Garb Ocaklarından Osmanlı donanmasına katılmak üzere hiç gemi gelmemişti ${ }^{18}$.

15 Venedik kaynakları, savaşın altı saat sürdüğünü belirterek savaşa katılan gemilerin hepsinin adlarını vermektedir (Anderson, Naval Wars, s. 155).

16 Venedik kaynakları, bu savaşta 358 kişinin esir alındığını kaydetmektedir (Anderson, Naval Wars, s. 155).

$17 \mathrm{Bu}$ kalyonlardan on biri tersanede tamir edilmişti (BOA, MAD, nr. 20220). Çanakkale Boğazı çıkışında yaşanan savaşın bütün safahatı konusunda bk. Kâtib Çelebi, Tuhfetü'l-kibâr fì Esfâri'l-Bihâr, haz. İdris Bostan, Ankara 2008, s. 213-214; Kara Çelebi-zâde, Ravzatü'l-ebrâr Zeyli, s. 205-206, 208; Abdi Paşa Vekâyi '-nâmesi, Osmanlı Tarihi, 1648-1682, haz. F. Ç. Derin, İstanbul 2008, s. 78-81; Silahdâr, Târih, İstanbul 1928 , I, 12-13. Venedik donanmasının Benefşe'ye saldırması ve diğer gelişmeler hakkında bk. Anderson, Naval Wars, s. 155156. Savaşın safahatı ve Osmanlı tarafının zayiatı hakkında farklı bilgiler için bk. Mugnai, The Cretan War, s. 151-153.

18 Anderson, Naval Wars, s. 153 


\section{Kalyonda Yaşanan Hezimet, 1656}

Girid savaşları sırasında Osmanlı donanmasında kalyon düzenine geçilmesinden sonra birtakım başarılar elde edilmiş olsa da tam anlamıyla bir etkinlikten bahsetmek mümkün değildir.

Osmanlı donanmasının kalyon döneminde yaşanan ilk önemli yenilgi 1656 senesinde Çanakkale Boğazı önündeki bozgun oldu. Bu sırada kaptanıderya Damad Sarı Kenan Paşa idi. Kenan Paşa, Silistre eyaletine tayin edildiği halde henüz görevine başlamak üzere iken Firari Kara Mustafa Paşa'nın Mısır beylerbeyliğine tayini sebebiyle Receb 1066 sonlarında (15-24 Mayıs 1656) kaptanıderyalığa getirildi ${ }^{19}$.

Kenan Paşa'nın kaptanıderyalığının ilk günlerinde Venedik'in yirmi dokuz kalyon, yedi mavna ve otuz bir kadırgadan oluşan donanmasının ${ }^{20} 23$ Mayıs'ta Çanakkale Boğazı girişine gelerek boğazın geçişini kapattıkları haberi alındı. Bu sırada Venedik donanmasından ünlü bir kaptan beraberinde otuz kişi ile birlikte kaçarak Boğaz muhafızı Çatalbaş Mustafa Paşa'ya sığınd1. Daha sonra İstanbul'a gelen ve Müslüman olan bu kaptana Şa ‘ban 1066'da (Haziran 1656) Tersane'de bir kapudanlık görevi verildi ${ }^{21}$. Karaçelebi-zâde'nin verdiği bu bilginin 1656-57 tarihli tersane muhasebe defterlerindeki kayıtlarla örtüştüğü tespit edilmektedir. Nitekim 1657'de sefere çıkan Osmanlı donanmasındaki kalyonlar arasında yeni Müslüman olmuş Ahmed isimli bir kapudan için bir kalyon, yine yeni Müslüman olmuş Hüseyin adlı bir reis için bir kadırga inşa edilmiş olması bu bilgiyi teyit etmektedir. Donanmada ayrıca Ali Kapudan ile Korfulu İbrahim Reis için inşa edilmiş birer kalyonun yer alması, bunların Venedikli “ünlü kapudan”ın emrindeki denizciler olmasını düşündürmektedir²2.

19 Kara Çelebi-zâde, Ravzatü'l-ebrâr Zeyli, s. 258, Abdi Paşa Vekâyi '-nâmesi, s. 90.

20 Venedik donanması içinde 11 Haziran'da Malta'dan gelen 7 kadırga da bulunuyordu (Anderson, Naval Wars, s. 159). Sadrazam Boynueğri Mehmed Paşa'nın (1656), IV. Mehmed'e takdim ettiği bir arzında da Boğaz muhafızı Çatalbaş Mustafa Paşa'dan kendisine gelen bir mektupta, Venedik donanmasına yardımcı olmak üzere Malta'dan yedi kadırga ve iki şeytiye geldiği bilgisinin yer aldığını bildiriliyordu (TSMA.E, nr. 5034). Bu bilgi, Anderson'ın Venedik kaynaklarına dayanarak verdiği bilgiyi Osmanlı belgelerinin teyid ettiğini göstermektedir.

21 Ravzatü'l-ebrâr Zeyli, s. 259. Anderson, kaptan ve mürettebatın Osmanlı tarafına sığınması ve ihtida konusunda bir bilgi vermemektedir (Naval Wars, s. 159).

221 Şevval 1066-Evâhır-1 Ramazan 1067 (23 Temmuz 1656-3-12 Temmuz 1657) tarihli sadrazam Köprülü Mehmed Paşa ile kaptanıderya Topal Mehmed Paşa zamanında tutulan tersane muhasebe defterinde kayıtlı nev-müslim Ahmed Kapudanın kalyonunun inşasında 235 iş günü neccar, 85 iş günü burgucu ve 120 iş günü kalafatçı olmak üzere toplam 440 iş günü çalışılmış ve kendilerine toplam 140.827 akçe ödenmiştir. Yine nevmüslim Hüseyin'in kadırgasının inşasında 123 iş günü neccar, 50 iş günü burgucu ve 43 iş günü kalafatçı olmak üzere toplam 216 iş günü çalışılmış ve 67.016 akçe ücret ödenmiştir. Defterde bu kadırgaya 196 kürekçi ve 16 alatçı yerleştirildiği kayıtlıdır (BOA, MAD, nr. 5662, s. 45, 49, 59). Yine aynı defterde yeni Müslüman olmuş Ali Kapudan ile Korfoz'lu yani Korfulu İbrahim Reis'in (s. 60) yeni inşa edilen kalyonlarından da bahsedilmesi bütün bu kapudanların Çatalbaş Mustafa Paşa’ya sığınan Venedikliler olma ihtimalini göstermektedir. 
İstanbul'da gerekli hazırlıkları tamamladıktan sonra Kenan Paşa kırk kadırga, on mavna, otuz kalyon olmak üzere seksen gemiden oluşan Osmanlı donanmass ${ }^{23}$ ile 22

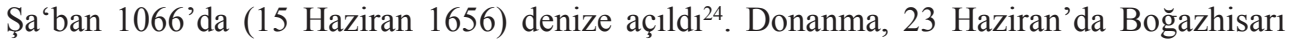
yani Kal'a-i Sultaniye’ye geldiğinde askerin sadece üçte biri mevcut bulunuyordu. Burada demirleyen Osmanlı donanması, karşısında tam teçhizatlı Venedik donanmasını görünce bir tereddüt geçirdiği için kaptanıderya bir kayıkla Rumeli kıyısına çıkarak orada bir meşveret meclisi topladı ve ne yapılması gerektiğini müzakere etti. Görüşme sırasında kaptanıderya, iki tarafın güçlerini karşılaştırarak Venedik askerinin sayı bakımından üstünlüğüne dikkat çektiği gibi, denizdeki akıntının da Venedik donanması lehine olduğunu ifade ederek daha fazla ve donanımlı asker temin edilmesi gerektiğinin İstanbul'a bildirilmesini söyledi. Buna karşılık Ocak askerlerinin yetkilileri, kendilerinin kaptanıderyanın emrine tâbi olduklarını, meselenin İstanbul'a sorulması konusuyla ilgilenmediklerini söyleyince toplantı bitmiş oldu. Bunun üzerine kaptanıderya bu defa bölgeden levent yazmaya teşebbüs ettiyse de paralarını savaştan sonra ödeyeceğini söyleyince leventler dağıldı.

Venedik kaynaklarına göre Osmanlılar, 24 Haziran'da boğazın iki yakasından Venedik donanmasını bölgeden uzaklaştırmak için top atışı gerçekleştirdi. Ancak bir sonuç alamadı ${ }^{25}$.

Bu durumda Osmanlı donanmasındaki gemilerin Venedik donanmasına uzak bir mesafeden geçip denize açılması gerekirken alınan emirler sebebiyle 4 Ramazan (26 Haziran) sabahı düşman donanmasına hücum edildi. Karşılıklı top ateşi sonunda kalyonlar yeterli sayıda asker olmadığı için savaşmak istemedi ve kalyonları terk ederek karaya çıktılar. Bu şartlar karşısında kaptanıderya emrine itaat eden kadırgalarla Venedik donanması üzerine yürüdü. Ne var ki gerek deniz akıntısının olumsuz etkisi gerekse rüzgârın o sırada muhalif esmesi sebebiyle Osmanlı donanmasındaki gemiler birbirine çarparak, kürek ve serenleri de birbirine çarparak karıştı. Mevcut kalyonlar, yedi mavna ve otuzdan fazla kadırga kenara yakın bir yerde demirlemek zorunda kald ${ }^{26}$. Bunu firsat bilen Venedik donanması saldırınca şiddetli

23 Venedik kayıtlarına göre savaşa katılan Osmanlı donanmasında yirmi sekiz kalyon, dokuz mavna ve altmış bir kadırga olmak üzere toplam doksan sekiz gemi idi (Anderson, Naval Wars, s. 159). Muhtemelen Çanakkale'de Osmanlı donanmasına bey gemilerinden katılanlar olmuștur.

24 Kâtib Çelebi, Tuhfetü' 'l-kibâr, s. 214; Kara Çelebi-zâde, dokuz mavna, elliden fazla kadırga ve otuz civarında kalyon (Ravzatü'l-ebrâr Zeyli, s. 260); Abdurrahman Abdi Paşa, donanma mevcudunu kırk beş kadırga, yedi mavna, yirmi yedi kalyon olarak zikretmektedir (Abdi Paşa Vekâyi '-nâmesi, s. 93). Naima ise, Abdi Paşa Vekâyi '-nâme'sindeki bilgileri tekrar etmektedir (Târih-i Na 'îmâ, haz. M. İpşirli, Ankara 2007, IV, 1674). Silahdâr, elli çekdirme, dokuz mavna, yirmi yedi kalyon (Silahdâr Mehmed Ağa, Silahdâr Târihi, I, 44). 17. Yüzyılın ikinci yarısına ait anonim bir Osmanlı tarihinde ise donanmanın hareket tarihi olarak 23 Şa'ban Cumartesi (16 Haziran) zikredilmektedir (Anonim Osmanl Vekayinâmesi, H. 1058-1106/M. 1648-1694, Metin ve Değerlendirme, haz. Ramazan Aktemur, İ.Ü. Basılmamış Yüksek Lisans Tezi, İstanbul 2019, s. 103/vr. 26a). Örfì Mahmud Ağa’nın eserinde de donanmanın 23 Şa ‘ban Cumartesi günü İstanbul'dan hareket ettiği ve yetmiş dokuz gemi bulunduğu bilgisi yer almaktadır (Mefhûmü t-tevârîh, TSMK, E.H. 1431, vr. 516a-b).

25 Anderson, Naval Wars, s. 159.

26 Kara Çelebi-zâde, Ravzatü 'l-ebrâr Zeyli, s. 261. Kâtib Çelebi, çarpışmanın başladığı günü 3 Ramazan (25 Haziran) olarak vermekte (Tuhfetü 'l-kibâr, s. 215) ise de Venedik kaynakları çatışmanın 26 Haziran'da olduğunu belirtir. 
bir çatışma oldu ve yüzme bilenler kıyıya çıkmış, diğerleri ise hayatını kaybetmişti. Bütün gemilerin düşman eline geçtiği bu hengamede Kapudan Paşa baştardası, sâbık kapudan Ali Paşazâde Abdülkadir Paşa ve Memi Paşazâdelerin en büyügü tarafindan kurtarılabildi. Yine derya beylerinden Memi Paşazadelerin küçük oğlu, Eğribozlu Mustafa Beyzadeler, Mühürdar Paşa kaimmakamı Yusuf Paşa, Cigalazâde, Ali Paşa'nın kardeşi Mehmed Paşa, Maryoloğlu Mustafa Paşa, Manca Çarıkzâde Boynu Eğri, Murad Bey, Hüsrev Beyzade kadırgaları ile bir mavna, savaş bölgesine gitmeye gücü yetmeyen yedi-sekiz kadar tersane gemisi kurtulmayı başardı. Ayrıca Veli Beyzâde, Keskin Paşazâde, Ayamavra Beyioğlu, Eğribozlu Zagayoğlu savaş bölgesi dışında oldukları için kurtulmuş oldu.

Osmanlı gemileri Kal'a-i Sultaniye önünü kapattıkları sırada Venedik donanması onların üzerine geldiğinden, o esnada kale topları kullanılamadığı için Abdurrahman Paşa, Tersane kethüdası Cici Bey, yine derya beylerinden Bayram Bey ve Himmet Bey'in gemileri ile on tersane gemisi, beş mavna, yedi yük kalyonu düşman eline geçti. Derya beylerinden Manca Çarıkzâde İbrahim Bey, on beş Tersane gemisi, iki mavna, yirmi kalyon yandı. Venedikliler ayrıca mühimmat olarak bin kadar top ve gemilerde bulunan çok sayıda esir aldı.

Kara Çelebi-zâde, kaybedilen gemi sayısını tek tek belirtirken Venedik'in on tersane gemisi, beş mavna, yedi burtun, dört bey gemisi olmak üzere toplam 26 gemiyi esir ettiğini, iki bey gemisi, on beş tersane gemisi, iki mavna ve yirmi burtun olmak üzere 39 gemiyi yaktığını zikretmektedir. Bu sayı toplamda altmış beş gemi olması gerektiği halde Kara Çelebi-zâde yetmişten fazla gemi kaybedildiğini yazmaktadır ${ }^{27}$.

Venedik kaynakları, savaşın ikinci günde de kısmen devam ettiğini, Osmanlılara ait dört büyük kalyon, iki pink, beş mavna, on üç kadırganın Venedik tarafından ele geçirildiğini, yirmi iki kalyon, dört mavna ve otuz dört kadırganın ya battığını veya yandığını belirtmektedir. Bu sebeple savaşta toplam olarak seksen dört Osmanlı gemisi kaybedilmişti²8.

Osmanlı kaynakları, Venedik donanmasından sadece üç kalyon ve iki Malta gemisinin yandığını, Osmanlı donanmasından ise top, tüfek gibi savaş malzemeleriyle dolu otuz kadırga ve kalyon yanında gemilerdeki yedi-sekiz bin Rus esirin Venediklilerin eline geçtiğini belirtmektedir ${ }^{29}$.

27 Ravzatü'l-ebrâr Zeyli, s. 262-263. Dönemin başka bir kaynağında ise zayi olan gemi sayısını seksen civarında vermektedir (Anonim Osmanlı Vekayinâmesi, s. 104/vr. 26a).

28 Anderson, Naval Wars, s. 159-160.

29 Ravzatü'l-ebrâr Zeyli, s. 263.; Kâtib Çelebi, Tuhfetü'l-kibâr, s. 214-215; Abdi Paşa Vekâyi'-nâmesi, s. 9394; Silahdâr, Tarih, I, 44-46. Venedik'in Çanakkale Boğazı'nı kapama teşebbüsleri ile ilgili ayrıca bk. Daniel Panzac, "Affrontement Maritime et Mutations Technologiques en Mer Egee:l'Empire Ottoman et la Republique de Venise (1645-1740)", The Kapudan Pasha: His Office and his Domain, ed. E. Zachariadou, Rethymnon 2002, s. 127-129. 
Venedik kaynaklarına göre ise, Venedik donanmasının gemi kaybı yakılan üç kalyon idi. Maddi kaybın yanı sıra 207 ölü, 260 yaralı ve 94 kayıpları vardı. Ayrıca 40 Maltalı ölmüş ve 100'den fazlası yaralanmıştı. Bununla beraber donanma komutanı Lazzaro Mocenigo yaralanmış ve bir gözünü kaybetmiş, Venedik Deniz Kuvvetleri Komutanı Lorenzo Marcello ise daha savaşın başında 26 Haziran'da ölmüş, ama bu husus gizlenmişti ${ }^{30}$.

Kâtib Çelebi, Osmanlı donanmasından kurtulan gemilerin sadece bir baştarda, bir mavna ve on yedi kadırga, Abdi Paşa ise, bir baştarda, yedi-sekiz tersane gemisi, on iki bey gemisi olduğunu belirtmektedir ${ }^{31}$.

Bu savaşın galibi olarak Venedik, çok geçmeden Bozcaada üzerine gitmiş ve ada muhafızı Vezir Abaza Ahmed Paşa'nın tedbirsiz davranması yüzünden kuşatmanın dokuzuncu gününde 21 Ramazan 1066'da (13 Temmuz 1656) vire ile adayı teslim almıştı. Çok geçmeden de Ağustos 1656'da Limni, Venedik tarafından işgal edilmişti. Halbuki henüz 1656'daki Osmanl1-Venedik savaşı vuku bulmadan önce Bozcaada kadısı Resul Efendi, on sekiz Venedik kalyonunun boğazı kapatmak için 2 Cemâziyelâhır 1066'da (28 Mart 1656) boğaza geldiklerini görmüş, kadırga ve mavnalarının da gelmek üzere olduğunu, adada asker olarak yirmi-otuz yamak dışında muhafaza edecek kimse olmadığını, eğer asker gönderilmezse adanın korunmasının imkansız olduğunu Divan'a bildirmişti ${ }^{32}$.

\section{Yenilginin Sosyo-Kültürel Etkileri}

Bu felaketi "İnnâ lillâhi ve innâ ileyhi râci'ûn" ${ }^{33}$ dua ayetini zikrederek bir vefat haberi almış gibi nakleden Kara Çelebi-zâde'ye göre donanmanın bu mağlubiyeti 1571'deki İnebahtı/Sıngın yenilgisinden sonraki en büyük kayıptı ${ }^{34}$.

$\mathrm{Bu}$ savaşlarda uğranılan mağlubiyeti değerlendiren Kara Çelebi-zâde, asıl sebebin Venedik'e ahidnâme verilmiş olmasına rağmen, Girid hâkimi de bir hainlik yapmamışken, Osmanlıların ada halkını esir etmek, öldürmek ve topraklarından sürmek suretiyle haksız yere Girid'i tahrib etmeleri olduğunu belirtmektedir. Buna başka bir örnek daha getiren Kara Çelebi-zâde, II. Murad'ın 843 senesinde (1439) eman verilmiş olan Sırp kralı Vılıkoğlu'nun

30 Anderson, Naval Wars, s. 160-161. Ayrica bk. Mugnai, The Cretan War, s. 153-154. Girid seferleri sırasındaki Venedik deniz kuvvetleri komutanları ile donanma komutanlarının listesi için bk. Bruno Mugnai-Alberto Secco, La Guerra di Candia, 1645-1669/The War of Candia, 1645-1669, Zanica 2017, c. 2.

31 Kâtib Çelebi, Tuhfetü'l-kibâr, s. 215. Abdi Paşa Vekâyi '-nâmesi, s. 94. Örfî’ye göre de bir baştarda, sekiz tersane gemisi kadırga ve on iki bey gemisi kurtulmuştu (Mefhûmü t-tevârîh, vr. 516b).

32 TSMA.E, nr. 6907/1. Bozcaada dizdarı Ahmed de Kapudan Paşa'ya gönderdiği mektupta 4 Cemâziyelâhır'da (30 Mart) Venedik'e ait yirmi kalyonun boğazın ağzında toplandıklarını haber vermiştir (TSMA.E, 6907/2).

33 Kur'ân-1 Kerim, Bakara Suresi, âyet 156. "Doğrusu biz Allah'a aidiz ve kuşkusuz O’na döndürüleceğiz" (Diyanet Meâli).

34 Ravzatü'l-ebrâr Zeyli, s. 265, 275. Naima, devrin şairlerinin bu yenilgi sebebiyle savaştan yüz çeviren askeri kınayan şiirler söylediklerini ve "Verdiler küffâra donanmayı bî-ceng ü cidâl" mısraını tarih düşürdüklerini belirtmektedir (Târih-i Na îmâ, IV, 1679). 
(Georges Brankoviç) iki oğlu ile aynı zamanda Eflak hakimi Drakula (Wlad-Drakul) ve iki oğlu Engürüs seferine çağrıldıkları zaman askerleriyle ordugaha geldiklerini, buna rağmen bazı kötü düşünceli kimselerin etkisiyle kalelere sürgüne gönderilerek hapsedildiğini, kurtulmak için hiçbir ümitlerinin kalmadığını, bu yüzden birkaç sene fetih yapılamadığını ve bunun uğursuzluk olduğunu zikreder.

Buna ait tarih kitaplarında da pek çok örnek olduğunu belirten Kara Çelebi-zâde, yenilginin bir diğer sebebi olarak da Girid seferi bahanesiyle Rumeli ve Anadolu halkına ağır vergiler konulmasını, bazı devlet adamlarının birçok bid'at vergi ihdas ederek düşman donanmasına karşı koymak üzere kalyon inşası için haksızlık yaptıklarını, fakir insanların mallarını çeşitli yollarla müsadere ettiklerini anlatmaktadır. Hatta, 'halkın ciğerparesi evladının kanı ve fukaranın iç yakan gözyaşı ile yapılan gemilerden ne hayır gelir, ya düşman eline geçer, ya denize batar' manasına gelen şöyle bir yorum yapmaktadır: "Hûn-ı ciğer-pâre-i re 'âyâ ve eşk-i dîde ve âh-ı derûn-ı fukarâ ile sûret-pezîr olan gemilerden ne makūle hüner-i cilve-ger-i manassa 'sudûr ola. Mukarrer ki ya nasîb-i a 'dâ veya gûte-hâr-ı lücce-i deryâ olup"35.

Bunlar dışında, görüşlerini sadece fakir halkın parasıyla yapılmasındaki haksızlığa bağlamaz, manevi olarak askerlerde yeterince samimiyet olmadığı ve düşmana korku salacak bir vakar bulunmadığı şeklinde de izah etmeye çalışır. Hatta Girid seferinin uzamasının ve zafer kazanılamamasının sebebi olarak yöneticileri suçlayarak, İslam askerlerinin kalplerinde metanet, görünüşlerinde heybet kalmamasına, donanma her defasında yenildiği halde devlet adamlarının bir türlü akıllanmamasına şaşırmaktadır.

Buna karşılık helal gelirle az da olsa yirmi gemi yapılmasının ve fukaranın duasının alınmasının önemine vurgu yapan ve Allah'a tevekkül edilmesini tavsiye eden Kara Çelebizâde bu takdirde düşmanın yüz gemisine galip gelineceğini iddia eder ${ }^{36}$.

Bu yaklaşım, Kıbrıs Seferine (1570-1571) karar veren Osmanlı ricaline karşı Venedik ile arada sulh olduğunu ileri sürerek itiraz eden veziriazam Sokollu Mehmed Paşa'nın gerekçeleriyle bir benzerlik göstermektedir. Nitekim Kıbrıs fethedilmiş olsa da nihayet ertesi sene 1571'de İnebahtı' da Osmanlı donanması adeta imha edilerek büyük bir bedel ödenmişti. Aslında Kıbrıs'a sefer düzenlenmesi konusunda hayli endişelenen Sokollu'nun yaklaşımının aynı zamanda onun da ne kadar ileri görüşlü bir devlet adamı olduğunu göstermektedir.

35 Ravzatü'l-ebrâr Zeyli, s. 263-265. Fakir halktan para toplayarak yapılan kalyonların akıbetlerinin iyi olmayacağı konusunda daha 1061'de (1651) Melek Ahmed Paşa'nın kendisinin yaptırdığı kalyonun denize indirilmesi sırasında içine su alması ve kısmen batması yüzünden çok söz söylendiği tarihçiler tarafından dile getirilmektedir. Bu konuda tafsilat için bk. Bostan, "Kadırgadan Kalyona”, s. 189.

36 Ravzatü'l-ebrâr Zeyli, s. 265. Naima da, İnebahtı yenilgisine benzettiği bu mağlubiyeti adeta Kara Çelebizâde'nin bilgilerini tekrar ederek anlatır, ancak onun devrin ricali hakkındaki tenkitlerini doğru bulmaz ve meselenin çözümü böylelerinin kendisine sorulsa doğru bir cevap veremeyeceğini kaydeder (Târih-i Na îmâ, IV, 1679-1681). 
Kara Çelebi-zâde, aldığı bir haberden de bahsederek Enderun hazinesinden külliyetli miktarda para ayırmak ve halktan da eskisi gibi ziyadesiyle destek istemek suretiyle bahara kadar kırk-elli mavna ve kalyon ile kırk kadar kadırga yapılmasının düşünüldügünü ve böylece Venedik'ten yenilginin intikamının alınacağı bilgisini nakletmektedir. Bu karardan da çok rahatsız olan Kara Çelebi-zâde, İstanbul'un fethinden itibaren Girid seferine kadar donanmada kalyon ve mavna kullanılmadığını ve sadece kadırgalarla pek çok zafer kazanıldığını belirterek bu konudaki ısrarını sürdürmüştür ${ }^{37}$. Bu hususta Kâtib Çelebi ile aynı görüşte olduğu anlaşılan Kara Çelebi-zâde'nin ya kendi tetebbuâtı sonunda bu karara vardığı veya eserini yazdığı zaman Tuhfetü'l-kibâr'ı görmüş olduğu tahmin edilebilir ${ }^{38}$.

Kara Çelebi-zâde, değerlendirmelerine İnebahtı üzerinden devam eder ve aslında İnebahtı/Sıngın yenilgisinin asıl sebebinin kapudan ve serdar arasındaki anlaşmazlıktan kaynaklandığını belirtir. Kalyon ve kadırgalar arasında mukayese yaparken ise, bir kalyonun üç-dört kadırga maliyetine denk olduğunu, rüzgâr müsait olmadığı zaman ise, her birini çekmek için birkaç kadırga gerektiğini ve bu durumun kadırgaların âtıl kalmasına sebep olduğunu ileri sürer.

Girid Seferi münasebetiyle cereyan eden savaşlarda zafer kazanmış bir kalyonun bulunmadığını, düşmana pişkeş olmaktan başka bir işe yaramadıklarını belirtir. Kadırgaların geri plana çekilip kalyon ve mavna yapımına öncelik verilmesinin ne kadar hatalı olduğunu dile getiren Kara Çelebi-zâde, boş yere gereksiz masraf yapıldığını, bu yüzden halka eziyet edildiğini, iş bilir kimselerle konunun istişare edilmemesini ciddi manada tenkid eder. $\mathrm{Bu}$ kararların alınmasında ve ilk kalyon inşasında rolü olan önceleri kaptanıderya (1649-1650) iken nihayet sadaret kaymakamı olan Haydar Ağazâde Mehmed Paşa ${ }^{39}$ (1656), şeyhülislam Mesud Efendi (1656), Anadolu kazaskeri Esad Efendi ve Rumeli kazaskeri İbrahim Efendi gibilerin yanlış düşüncelerinin acı sonucu olduğunu zikreder. Padişahın ise bu konulardan haberi olmadığı için alınan kararların doğru olduğunu zannettiğini belirtir.

Kara Çelebi-zâde'ye göre, eğer halkın ne kadar zor durumda olduğunu bilirse padişahın gereksiz olan bu vergileri iptal edeceği aşikardır. Padişaha bir hakikatli vezir gelmesi temennisinde bulunan Kara Çelebi-zâde, istiklal sahibi bir sadrazamın kötü giden işleri düzelteceğini ümit eder. Kalyon ve mavna yapılmasından vazgeçilmesi ve kadırgalar hazırlanarak bahar mevsimine yetiştirilmesinin doğru olduğunu savunur. Ayrıca karadan ünlü bir serdar komutasında orduların Zadar ve civarındaki kaleleri ele geçirmesi, Osmanlı topraklarından düşmana zahire gönderilmesinin önüne geçilmesi, Dubrovnik iskelesinin dışarıya kapatılması, Hırvat ve Arnavut eşkıyasının kontrol altına alınması istenir.

37 Ravzatü'l-ebrâr Zeyli, s. 265.

38 Kâtib Çelebi, Tuhfetü'l-kibâr, s. 205.

39 Hayatı hakkında bk. Bostan, Ístanbul'un 100 Denizcisi, s. 118-120. 
Tersane masrafı çok fazla olduğu için o konuda da gerekli kısıntıların yapılmasını isteyen Kara Çelebi-zâde, tecrübeli denizcilerin sözbirliği halinde Rodos Paşasının otuz kadar derya beylerinin üzerine serdar tayin edilmesinin önemini vurguladıklarını alacakları bütün ganimetlerin onlara verilmesi karşılığında gaza ve cihada teşvik edilmelerini tavsiye eder. Bu durumda derya beylerinin hep birlikte Venediklilerin hakkından geleceğine ve denizlerin düşman gemilerinden temizleneceğine, pek çok adayı ele geçireceklerine inanır. Böylece Malta ve Duka gemilerinin de birer birer yakalanıp getirileceğini dile getirir ${ }^{40}$.

Kara Çelebi-zâde, Tersanenin sadece yelken, halat, kürek temin etmesi ve Mısır'dan yeteri kadar siyah barut gönderilmesi halinde donanmanın ihtiyacı olan mühimmatın tamamlanmış olacağından bahseder. Bu takdirde pek çok gelir kalemi ve gemi inşası için gerekli masraf kalemleri, avarız akçesi, peksimed vs. gelirler hazineye kalır ${ }^{41}$. Bu sayede (gemi yapımından vazgeçilince) gemilerin inşası için gerekli olan kerestelerin temininde görevlendirilen halk da çektiği mali ve bedeni haksızlıklardan kurtularak devlete dua ederler. Yine donanmadaki savaşçılar, alacakları esir ve ganimetin kendilerinin olacağını bilirse çok daha iyi savaşırlar. $\mathrm{Bu}$ inceliklere vakıf olanlar yönetimde olmadığg ve sadece buldukları düzeni sürdürdükleri için iyi sonuç almanın zor olduğunu belirtir².

Kara Çelebi-zâde, hakikat olan bu tenkitlerinin, meselelerin inceliklerine vakıf olmayanlar tarafından kendisinin bir makam elde etmek amacıyla yazdığına hamledilerek kasıtlı olduğunu düşünseler de amacının devleti kayırmak olduğunu, belki ehl-i insaf bazı kimseler tarafından padişaha ulaştırılır ve bu sayede devlete bir düzen verilir diye ümit ettiğini açıklar. Kendisinin ne padişah ne de vezirle bir ilgisinin olmadığını, dünyada da bir ikbalde gözü olmadığını ifade eder ${ }^{43}$.

\section{İlk Kalyon Döneminin Sonu}

Bununla beraber kalyonların önemini ve üstünlügünü koruduğunu, aynı sene yeni kalyonların inşası için verilen ve Sinop kadısına gönderilen 20 Şevval 1066 (11 Ağustos 1656) tarihli hükümden ve ayrıca diğer kalyon inşa edilecek yerlere ait bir listeden anlamak mümkündür. Buna göre Sinop, Samsun, Ereğli, Balıklağı, Varna, Kemer, İzmit ve Silivri'de yirmi kalyon inşası kararlaştırılmıştı ${ }^{44}$.

Ancak bu karardan yaklaşık yirmi gün sonra, IV. Mehmed'in riyasetinde Yalıköşkü’nde (Çayır Köşkü) sadrazam, vezirler, şeyhülislam ve yeniçeri ağasının da katıldığı bir meşveret meclisi toplanmış, mesele bütün ayrıntılarıyla müzakere edilmiş ve kalyon yapımından

40 Ravzatü'l-ebrâr Zeyli, s. 266-268.

41 Ravzatü'l-ebrâr Zeyli, s. 269.

42 Ravzatü'l-ebrâr Zeyli, s. 270.

43 Ravzatü'l-ebrâr Zeyli, s. 270-271.

44 Sinop'tan dört kalyona yetecek kereste temin etmesi isteniyordu (BOA, $M A D$, nr. 9837, s. 105). 
vazgeçilmiştir. Bu toplantıda alınan Evâil-i Zilka‘de 1066 (21-30 Ağustos 1656) tarihli karara göre, geleneksel olarak donanmada kullanılması tercih edilen kadırgaların yapımına devam edilmesi emrediliyordu ${ }^{45}$.

Çanakkale Boğazı çıkışının ve Batı Anadolu sahillerinin büyük tehdit altında olduğu düşünülerek 9 Zilka‘de (29 Ağustos) günü yapılan toplantıda alınan kararlar gereği acil olarak bazı yeni tayinler yapıldı. Buna göre, Midilli’yi muhafaza etmesi şartıyla Anadolu beylerbeyi Bayram Paşa’ya Aydın sancağı, İzmir sahillerini korumak şartıyla Mustafa Paşa'ya Saruhan sancağı arpalık olarak verildi. Ertesi gün 10 Zilka'de'de (30 Ağustos) de yeni tayinler yapılmaya devam edilen Divan'da, Sakız adasını korumaları kaydıyla Menteşe sancağı Ahmed Paşa'ya, Karaman eyaleti Tekeli Ahmed Paşa'ya, yine 11 Zilka'de'de (31 Ağustos) Beyşehir sancağı başka bir Ahmed Paşa'ya tevcih edildi ${ }^{46}$. Böylece, savaşın sonunda Venedik tarafından işgale uğrayan Limni ve Bozcaada'nın akıbetine diğer adaların ve İzmir'in uğramaması için bu tedbirler alınmış oldu.

Çok geçmeden Köprülü Mehmed Paşa’nın sadarete getirilmesi (26 Zilka'de 1066/15 Eylül 1656) ile alınmaya başlayan tedbirler arasında Tersane eminliğine getirilen Şişman İbrahim Efendi'nin gayretleri sonunda yapılması istenen altmış kadırgadan ${ }^{47}$ ancak kırk kadırga tamamlanmıştı. Ertesi sene henüz deniz mevsimi gelmeden, sırf Venedik donanmasının Çanakkale Boğazını kapatmasından önce Akdeniz’e açılabilmek için kırk kadırgalık Osmanlı donanması kaptanıderya Topal Mehmed Paşa komutasında 28 Cemâziyelevvel 1067'de (14 Mart 1657) İstanbul'dan ayrıld $1^{48}$. Bu donanma Sakız'da iken Cezayir'den sekiz, Tunus'tan on ve Trablusgarb'den sekiz kalyon katılmıştı ${ }^{49}$.

Daha sonraki senelere ait Tersane muhasebe defterlerinde de yeni kalyon inşa edildiğine dair şimdilik bir kayda rastlanmaması bu kararın geçerli olduğunu ortaya koymaktadır. Sadece eskiden mevcut kalyonların zaman zaman tamir edildiğini belirtmek gerekir ${ }^{50}$.

45 Ravzatü'l-ebrâr Zeyli, s. 287. Abdurrahman Abdi Paşa bu meşveret meclisi toplantısının 15 Zilka'de (4 Eylül) tarihinde yapıldığını (Abdi Paşa Vekâyi'-nâmesi, s. 97) kaydetmiş olsa da, Kara Çelebi-zâde, Evâil-i Zilka‘de'de (21-30 Ağustos ) yapıldığını belirtmekte (Ravzatü'l-ebrâr Zeyli, s. 287), bu toplantıda alınan kararların 9 Zilka'de'den (29 Ağustos) itibaren uygulamaya konması da bunu teyit etmektedir. Toplantı tarihi hakkında bir değerlendirme için bk. Ersin Gülsoy, Girit'in Fethi ve Osmanlı İdaresinin Kurulması (16451670), İstanbul 2005, s. 111-112, dipnot 79-80.

46 Gülsoy, Girit'in Fethi, s. 111-112.

47 Söz konusu altmış kadırganın bilâhıre tamamlandığı İbrahim Efendi’nin tuttuğu 1 Rebî‘ülevvel 10718 Cemâziyelevvel 1072 (4 Kasım 1660-1 Kasım 1661) tarihli tersane muhasebe defterinden anlaşılmakta, defterde yeni inşa edilen kadırgalar reislerinin adı altında tam bir liste halinde verilmektedir (BOA, MAD, nr. 996, s. 39-43).

48 Silahdâr, Târih, I, 57, 69. Kara Çelebi-zâde, donanmada 32 kadırga bulunduğunu yazmaktadır Ravzatü'l-ebrâr Zeyli, s. 297.

49 Silahdâr, Târih, I, 72.

50 Kalyon inşasının durmasından sonraki bazı istisnai durumlar için bk. Bostan, "Kadırgadan Kalyona”, s. 190. 
Köprülü Mehmed Paşa'nın (1657-1661) ölümü üzerine sadrazam olan Fazıl Ahmed Paşa (1661-1676), Merzifonlu Kara Mustafa Paşa’yı (1661-1666) kaptanıderya tayin etmiş ve bahriyede ıslahat yapılması sürecini başlatmıştır. Bunun gereği olarak, daha önce alınan kalyonları kaldırma kararının sürdürülmesi ve donanmada yeniden kadırga dönemine dönülmesi uygun görülmüştür. $\mathrm{Bu}$ karara göre, tersanede artık mirî kalyon ve mavna yapılmayacak, eskiden olduğu gibi, ocaklık kırk kadırga ve derya beylerinin emrinde kırk kadırga olmak üzere toplam seksen kadırgadan oluşan bir donanma bulundurulacakt ${ }^{51}$. Bu karar üzerine kalyon döneminin ilk safhası kesin olarak sona ermiş oldu.

\section{Sonuç}

Girid seferi münasebetiyle Osmanlı donanmasında yaşanan değişimin deniz savaşlarına yansıması henüz yeterince değerlendirilmemiştir. Bu sefer sırasında alınan bir kararla Osmanlı kürekli gemi teknolojisinin yelkenli gemiler gibi tamamen farklı bir teknolojiye dönüşmesi üzerinde dikkatle durulması, kalyon yapımının devlet ve toplum düzenine iktisadi yansımaları, eski düzen bir donanma bünyesine kalyonun teknik ve taktik olarak adapte olamaması, donanma ümera ve mürettebatında kalyon tecrübesinin henüz oluşmamış olması, hızla geçilen kalyon düzeninde savaşçı denizcilerin layıkıyla yetişmemiş olması konuları iyice araştırılmalıdır.

Genellikle yenilgi ile sonuçlanan savaşlarda birtakım suçlu komutan ve savaş araçları aranması, bunların üzerine gidilmesi adettir. Kara Çelebi-zâde gibi münekkid tarihçilerin o zamanın şartlarında sebepler arasında pek çok gerekçe öne sürmesi de elbette kaçınılmazdır. Nitekim aynı dönemde Kâtib Çelebi'nin de benzer gerekçelerle ilk kalyon inşası sırasında kendisinden görüş soran Şeyhülislam Abdürrahim Efendi'ye geleneksel gemi teknolojisinin yani kadırganın üstünlüğünü işaret eden bir tavsiyede bulunduğu bilinmektedir. Üstelik Kara Çelebi-zâde'nin gerekçelerinin anlaşılabilir yanları göz ardı edilemez olsa da, o devirde etkin görevlerde olan kendi rakibi bazı devlet adamlarını da suçlama gayreti içine girdiği ve denizdeki yenilgiyi firsat gördüğ̈̈ fark edilmektedir.

Kabul edilmesi gerekir ki, bu tür süreçlerde her zaman acemiliklerin yaşanması tabiidir ve kendi teknolojisini ve uzman kadrolarını oluşturana kadar bu eksikliğin bedelinin olması da söz konusudur. Nitekim bahriyede yapılması planlanan ıslahatlar arasında 1682'de başlayan ikinci dönem kalyon düzeni sırasında yine Venedik donanması ile Kaptanıderya Mezemorta Hüseyin Paşa komutasındaki donanma arasında yaşanan deniz savaşlarında Osmanlı galibiyetlerinin sayısı hayli yüksektir. Bu sebeple yaklaşık yirmi yıl süren deniz savaşları tecrübesinden sonra 1701'de uygulamaya koyulan Bahriye kanunnamesi sayesinde Osmanl donanması yeni bir düzene geçmeyi başarmış, 18. yüzyıla bu gelişmeler çerçevesinde girmiştir.

51 Silahdâr, Târih, I, 221. 
Hakem Değerlendirmesi: Dış bağımsız.

Çıkar Çatışması: Yazar çıkar çatışması bildirmemiştir.

Finansal Destek: Yazar bu çalıșma için finansal destek almadığını beyan etmiștir.

Peer-review: Externally peer-reviewed.

Conflict of Interest: The author has no conflict of interest to declare.

Grant Support: The author declared that this study has received no financial support.

\section{Kaynakça/References}

\section{Arşiv Kaynakları}

\section{Türkiye Cumhuriyeti Cumhurbaşkanlığı Devlet Arşivleri Başkanlığı Osmanlı Arşivi (BOA)}

Maliyeden Müdevver Defterler (MAD), nr. 996, 5662, 9837, 20220.

Topkapı Sarayı Müzesi Arşivi Evrakları (TSMA.E.).

\section{Yazma Eser}

Mefhûmü't-tevârîh, TSMK, E.H. 1431.

\section{Yayınlanmış Eserler}

Abdi Paşa Vekâyi'-nâmesi, Osmanlı Tarihi, 1648-1682, haz. F. Ç. Derin, İstanbul 2008.

Anderson, R. C., Naval Wars in the Levant 1559-1853, Liverpool 1952.

Anonim Osmanlı Vekayinâmesi, H. 1058-1106/M. 1648-1694, Metin ve Değerlendirme, haz. Ramazan Aktemur, İ.Ü. Basılmamış Yüksek Lisans Tezi, İstanbul 2019.

Bostan, İdris, "17. Yüzyılın İkinci Yarısında Osmanlı Gemi Teknolojisinin Değişimi: Kadırgadan Kalyona”, Beylikten İmparatorluğa Osmanlı Denizciliği, İstanbul 2015, , Istanbul'un 100 Denizcisi, İstanbul 2014.

Gülsoy, Ersin, Girit'in Fethi ve Osmanlı İdaresinin Kurulması (1645-1670), İstanbul 2005.

Kara Çelebi-zâde Abdülaziz Efendi, Ravzatü'l-Ebrâr Zeyli (Tahlil ve Metin) 1732, haz. Nevzat Kaya, TTK, Ankara 2003.

Kâtib Çelebi, Tuhfetü'l-kibâr fî Esfâri'l-Bihâr, haz. İdris Bostan, Ankara 2008. , Fezleke [Osmanlı Tarihi (1000-1065/1591-1655)], haz. Z. Aycibin, İstanbul 2016, II.

Kur'ân-ı Kerim, Bakara Suresi, âyet 156, Diyanet Meâli.

Mugnai, Bruno, The Cretan War, 1645-1671, The Venetian-Ottoman Struggle in the Mediterranean, Warwick 2018. - Alberto Secco, La Guerra di Candia, 1645-1669/The War of Candia, 1645-1669, Zanica 2017, c. 2.

Panzac, Daniel, “Affrontement Maritime et Mutations Technologiques en Mer Egee: l'Empire Ottoman et la Republique de Venise (1645-1740)", The Kapudan Pasha: His Office and his Domain, ed. E. Zachariadou, Rethymnon 2002, s. 127-129.

Silahdâr, Târih, İstanbul 1928, I.

Târih-i Na ‘̂̀mâ, haz. M. İpşirli, Ankara 2007, IV. 